\title{
Quality Assurance in Asian Distance Education: Diverse Approaches and Common Culture
}
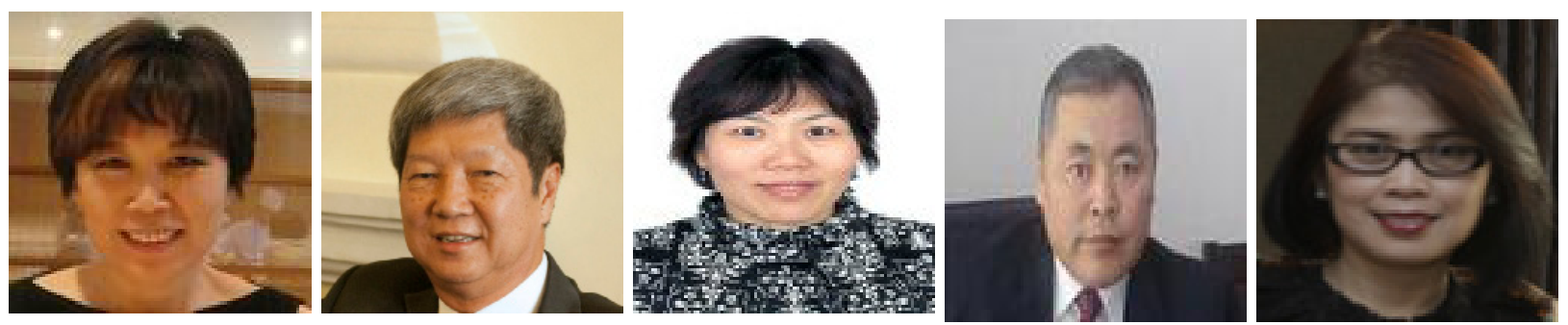

Insung Jung ${ }^{1}$, Tat Meng Wong ${ }^{2}$, Chen $\mathrm{Li}^{3}$, Sanjaa Baigaltugs ${ }^{4}$, and Tian Belawati ${ }^{5}$ ${ }^{1}$ International Christian University, Japan; ${ }^{2}$ Wawasan Open University, Malaysia; ${ }^{3}$ Beijing Normal University, China; ${ }^{4}$ Mongolia University of Science and Technology; ${ }^{5}$ Universitas Terbuka, Indonesia

\section{Abstract}

With the phenomenal expansion of distance education in Asia during the past three decades, there has been growing public demand for quality and accountability in distance education. This study investigates the national quality assurance systems for distance education at the higher education level in Asia with the aim of contributing to a better understanding of the current level of development of quality assurance in Asian distance education and to offer potential directions for policy makers when developing and elaborating quality assurance systems for distance education. The analysis of the existing quality assurance frameworks in the 11 countries/territories selected reveals that the level of quality assurance policy integration in the overall national quality assurance in higher education policy framework varies considerably. The purpose of quality assurance, policy frameworks, methods, and instruments in place are generally tailored to each country's particular circumstances. There are, however, obvious commonalities that underpin these different quality assurance efforts.

Keywords: Accreditation; distance education; e-learning; higher education; quality assurance

\section{Introduction}

Daniel (2003) suggests that there is ample evidence of distance education (DE) in Asia making great strides with regard to access, equity, and cost-benefit. What is uncertain, however, is whether DE in Asia is providing quality education.

Over the last few decades, there has been a substantial growth in DE in Asia. There are now at least 10 mega-universities, over 70 open universities, and a growing number of conventional institutions offering $\mathrm{DE}$, as well as a rapidly growing number of private and/ 
or for-profit DE providers operating in Asia (Latchem \& Jung, 2009). With the phenomenal expansion of DE and an increasing dependency on DE to provide education, especially higher and further education, there has been growing public concern over the quality of DE delivered.

The meaning of quality in DE, in particular, has attracted debate. As suggested by Perraton (2000), the goal of DE for some countries (or providers) is to achieve a level of quality on par with that of face-to-face education. However, Stella and Gnanam (2004) have suggested that $\mathrm{DE}$ is so distinctive that the aims and methods of face-to-face education cannot be applied in assessing its quality. Furthermore, as Koul (2006) has commented, DE should be judged by the standards of face-to-face education while factoring in some distinctive features of DE, such as open entry, flexible operations, and technology-based course delivery.

In addition, quality in DE has presented different meanings for governmental policy makers, institutional administrators, teaching staff, and students. Governments may be more interested in efficiency, cost-effectiveness, and public accountability (Koul, 2006), whereas DE providers may be more interested in the quality of their management, staffing, courses, and graduation rates (Hope, 1999). Teachers may be more concerned with the quality of the learning processes and outcomes (Jung, 2011), while students may be more preoccupied with the costs, flexibility, and interactions in their learning (Cashion \& Palmieri, 2002; Ehlers, 2004). Moreover, societal and cultural environments affect quality assurance (QA) policies and practices, as indicated in Jung's (2010) ecological model of QA in DE. QA depends upon reconciling all of these different perspectives, considering societal and cultural variations, and reaching agreement on the quality criteria and standards by which to judge the quality of input, process, and output of DE.

Various national, regional, and international initiatives have been undertaken with regard to QA in DE, including e-learning. Examples of national initiatives include the UK Quality Assurance Agency's Guidelines on the Quality Assurance of Distance Learning (see http://www.qaa.ac.uk/academicinfrastructure/codeofpractice/distancelearning/ contents.asp), the Norwegian Association for Distance Education's Quality Standards for Distance Education (see http://nettskolen.nki.no/forskning/DISTUMQualityAssurance. pdf), the Australasian Council on Open, Distance and E-Learning's benchmarks for DE and e-learning (see http://acode.edu.au/resources/ACODE_benchmarks.pdf), and the National Association of Distance and Open Education Organizations of South Africa's quality criteria for designing and delivering distance education. To mention a few examples of regional and international initiatives, the African Union Commission developed the African Higher Education (including DE) Quality Rating Mechanism (see http://www. africa-union.org/root/UA/Conferences/2007/aout/HRST/o6-10aout/AfricanHEQualityRatingMechanism-E.doc), the European Association of Distance Teaching Universities produced the Quality Manual for E-learning in Higher Education (see http://www. eadtu.nl/e-xcellenceQS/files/members/E-xcellenceManualGrey/index.html), the Asian Association of Open Universities offered the AAOU Quality Assurance Statements of Best Practice (see http://www.aaou.net/index.php?option=com_content\&view=category\& layout=blog\&id=29\&Itemid=30), and the International Council for Open and Distance 
Education launched a pilot project (see http://www.icde.org/?module=Articles;action= Article.publicShow; $\mathrm{ID}=1765$ ) to identify regulatory frameworks for distance and online education in different regions, to investigate the best practices, and to examine the rules and regulations hindering distance and online education development.

In Asia, several countries have recognized the need for well-defined QA policy frameworks for DE to assure that quality education is delivered to both students and the public, to safeguard against unscrupulous practices, and to initiate development of QA systems, specifically for DE. This study investigates national QA systems for DE at the higher education level in Asia. Its primary objective is to develop a better understanding of the current development of QA in Asian DE and to offer policy makers directions for developing and elaborating QA systems for DE in their own jurisdictions. DE in this study refers to various forms of technology/media-supported education, such as e-learning.

The study was carried out between January and December 2010 and employed three data collection steps: (a) 11 cases (10 countries and one territory) from East, South, and Southeast Asia were carefully chosen to include those with relatively well-established QA systems, those just introducing QA systems, and others still in the process of developing QA concepts in DE; (b) formal documents published by QA agencies (research institutes and governments in the selected countries/territories) and other references were analyzed to delineate DE development, QA policies, procedures, standards, and criteria for higher education in general and DE specifically; and (c) face-to-face, email, or telephone interviews with local experts working in the QA agencies and DE institutions were conducted to verify the data obtained. No quantitative data related to QA policy development and implementation (e.g., the number of accredited/assessed DE institutions, the number of QA criteria, and standards) were collected because they were not considered necessary for the purposes of this study. This paper outlines the development of DE in each of the 11 cases, discusses differences and similarities, and concludes with a set of recommendations for the further development of QA for Asian DE.

\section{Development of Distance Education}

The following section outlines the development of DE and national QA systems in China, Hong Kong SAR (China) (Hong Kong hereafter), India, Indonesia, Japan, South Korea (Korea hereafter), Malaysia, Mongolia, Philippines, Singapore, and Sri Lanka to provide a basis for subsequent analyses.

\section{China}

The Open University System of China (OUSC) (combining former China Central Radio and TV University, which was established in 1979, with other radio and TV universities across the country) was the country's sole DE provider for 20 years. Then, between 1998 and 2003, the Ministry of Education (MoE) licensed 68 online colleges operating from within conventional universities such as Tsinghua University, Peking University, Beijing Normal University, and other institutions to become online providers. By 2008, the number of ac- 
tive distance students in China was 3,560,000, or $12 \%$ of all students in the higher education sector. Of these, some 2,250,000 were studying through the OUSC, while 1,310,000 were in the online colleges. However, facing growing public concern over the quality of the courses and programmes offered, the MoE in 2003 ceased granting approval for new online colleges and introduced a QA system that required both the OUSC and online colleges to comply with the guidelines and documents provided by the MoE and imposed nationally standardized examinations upon them. The institutions were also required to follow the Annual Reporting and Censorship procedure, which involves annual internal reviews and external audits by the Distance and Continuing Education Office in affiliation with the Department of Higher Education of the MoE.

\section{Hong Kong}

DE arrived in Hong Kong with the establishment of the Open Learning Institute of Hong Kong (OLIHK) in 1989. OLIHK was granted self-accrediting status in 1996 by the Hong Kong Council for Academic Accreditation (HKCAA). In 1997, the OLIHK was conferred the title of university by the government and renamed the Open University of Hong Kong (OUHK). As of 2010, over 13,000 students were enrolled in the university's DE programmes. As a university with self-accrediting status, programmes offered by OUHK no longer need to be subjected to external accreditation. However, the institution is required to undertake periodic institutional audits. Other DE/online education institutions/programmes in Hong Kong include the Cyber University of the Hong Kong Polytechnic University, the Hong Kong Virtual University consortium, and the School for Professional and Continuing Education of the University of Hong Kong. In 2007, with the enactment of the Accreditation of Academic and Vocational Qualifications Ordinance (see http://www.legislation.gov.hk/ blis_pdf.nsf/6799165D2FEE3FA94825755E0033E532/o8A299C8E01C2F21482575EF o01FFE6F/\$FILE/CAP_592_e_b5.pdf) the HKCAA was renamed the Hong Kong Council for Academic and Vocational Qualifications (HKCAAVQ).

\section{India}

The Indira Gandhi National Open University (IGNOU) was established in 1985 and currently serves over 3.5 million students. Over the last two decades, 13 more state open universities and over 50 other $\mathrm{DE}$ institutions catering to $25 \%$ of all enrolments in higher education have emerged. The Distance Education Council (DEC) was established within IGNOU in 1991 to assess and provide oversight on the quality of DE in India. The DEC Handbook on Assessment and Accreditation of Open \& Distance Learning Institutions (see http://www.dec.ac.in/Revised_Copy_of_HANDBOOK_on_A_\&_A-version1.doc) provides guidelines and criteria for assessment and accreditation in DE. To qualify for employment in the government sector, holders of DE-based degrees and certificates graduate from institutions that are approved by the DEC.

\section{Indonesia}

Since the mid-1950s, Indonesia has used DE to train teachers, but it was not until 1984, when Universitas Terbuka (UT) was established, that DE became widely accepted and recognized within the country. Although it has been permissible for conventional universities 
to offer DE courses and programs since 2001, UT remains the only higher education institution that is entirely employing an open and distance education system in Indonesia. UT's total student body was over 650,000 as of 2010 . As a public university, UT must adhere to all of the quality standards and regulations applicable to higher education institutions in Indonesia, including the submission of semester-based self-assessment reports to the Ministry of National Education. UT has been accredited by the independent National Accreditation Board of Higher Education (BAN-PT). In addition, UT has voluntarily sought accreditation from other international organizations, including the International Council for Open and Distance Education (ICDE) and the International Organisation for Standardisation/ISO for ISO 9001:2000/2008.

\section{Japan}

The Open University of Japan (OUJ) (formerly the University of the Air) first offered bachelors' programmes in the greater Tokyo area through terrestrial TV and radio and correspondence in 1985. In 1998, it went nationwide, using satellite digital broadcasts and a network of study centres. It served almost 100,000 students in 2010. Since 2001, OUJ has also provided graduate programmes, but e-learning has not yet been mainstreamed into OUJ's system. Besides OUJ, 42 conventional universities, two cyber universities, and several graduate schools also offer DE programmes. Since 2004, all higher education institutions have needed to be reviewed and accredited every seven years by one of three QA agencies approved by the Ministry of Education, Culture, Sports, Science and Technology. These are the National Institute of Academic Degrees and University Evaluation (NIADUE), the Japanese University Accreditation Association (JUAA), and the Japanese Institute for Higher Education Evaluation (JIHEE). Despite this, no specific QA or accreditation system has been established for DE institutions or their programmes.

\section{Korea}

The Korea National Open University (KNOU), established in 1972, was the sole DE provider in Korea until the Ministry of Education, Science and Technology (MEST) legislated for the creation of cyber universities in 2001. As of 2010, there were 18 cyber colleges and universities offering bachelors' and masters' degrees in various majors. KNOU has over 170,000 students, while the cyber universities served over 30,000 students in 2010. All universities offering four-year programmes, including KNOU, must conduct self-evaluations at least once every two years and submit their findings to the Korean Council for University Education (KCUE) - the only government-recognized agency allowed to accredit four-year universities as of 2011. In the case of cyber universities, the Korea Education and Research Information Service (KERIS) monitors their quality programmes based on guidelines established in the Cyber University Evaluation Handbook.

\section{Malaysia}

DE programmes have been offered by DE units located within conventional universities such as the University of Science, Malaysia since the 1970s. During the past decade, three dedicated distance universities have been established in Malaysia: Open University Malaysia, established in 2000, Wawasan Open University in 2006, and Asian e-University 
in 2008. Together they served approximately 90,000 distance learners in 2010. The Malaysian Qualifications Agency (MQA) was established in 2007 to monitor the QA practices of all higher education institutions-including distance universities-and to accredit their programmes. Until 2010, programmes offered by the DE universities were accredited using guidelines, criteria, and standards developed for conventional universities. In Malaysia, both conventional and DE programmes must first obtain provisional accreditation from the MQA before approval can be given by the Ministry of Higher Education for student recruitment. Programmes with a provisional accreditation status are required to undertake the full accreditation audit in the semester prior to the graduation of their first graduates. Universities that have successfully completed several cycles of programme accreditation may be invited by the Minister of Higher Education to undertake an institutional audit, the successful completion of which can lead to the awarding of self-accrediting status. Institutions with self-accrediting status are no longer required to undertake programme accreditation.

\section{Mongolia}

Mongolia does not have any dedicated DE institutions. However, some DE programmes are offered by a number of institutions, including four public universities (Mongolian University of Science and Technology [MUST], National University of Mongolia, University of Health Science, and Mongolian Educational University) and a few private institutions. Among these universities and institutions, MUST has been the most active in developing and implementing e-learning programmes. Between 2007 and 2010, MUST offered 16 masters' degree programmes online as well as integrated ICT in the delivery of its undergraduate courses. The Mongolian National Council for Education Accreditation (MNCEA) was established as a government initiative in 1998 to evaluate and accredit universities and colleges in an attempt to address public concerns over the quality of higher education. In 2002, it started accrediting vocational and technical institutions as well.

\section{Philippines}

As an archipelago of 7,100 islands, the Philippines would seem to be an ideal place for the development of DE. However, only 17 higher education institutions offer DE programmes. Among the existing standalone DE providers are the University of the Philippines Open University (UPOU), which is part of the University of the Philippines System, CAP College, the Asian Institute for Distance Education, and the Southeast Asia Interdisciplinary Development Institute. The rest are conventional universities offering a few of their programmes by way of DE. Most of the DE provision is at the graduate level, which would perhaps account for the low DE student enrolments nationwide. As of 2010, UPOU, the most comprehensive DE institution in the country, offered only two undergraduate programmes and had a total enrolment of about 2,500 students per semester. Public institutions are monitored and assessed by the Commission on Higher Education (CHED) and undergo voluntary accreditation by the Accrediting Association of Chartered Colleges and Universities of the Philippines. Private institutions are required by CHED to be certified by the Federation of Accrediting Agencies of the Philippines, which includes the Philippine Accrediting Association of Schools, Colleges and Universities and the Philippine Association of Colleges and Universities' Commission on Accreditation. 


\section{Singapore}

The government of Singapore currently does not accredit programmes or higher education institutions. However, the Higher Education Quality Assurance Section of the MoE has been auditing universities that offer four-year degree programmes under the Quality Assurance Framework for Universities (QAFU) since 2004. The main DE provider in Singapore, UniSIM, uses a blended approach for delivering education wherein e-learning is used to supplement face-to-face classes. Its emergence can be traced back to 1992, when the MoE appointed the Singapore Institute of Management (SIM) to collaborate with the UK Open University to offer the Open University Degree Programme (OUDP). In 2002, OUDP was granted accreditation status by the UK Open University and renamed SIM Open University Centre (SIM-OUC). In 2005, SIM-OUC was granted full university status and renamed UniSIM. As of 2010, UniSIM served over 11,00o students and fell under the MoE's Quality Assurance Framework for Universities (see http://www.moe.gov.sg/media/press/ files/2003/05/report.pdf) in terms of its institutional QA audit.

\section{Sri Lanka}

Since its establishment in 1978, the Open University Sri Lanka (OUSL) has been the only DE provider. In 2010, it had an enrolment of around 25,000 students. In recent years, with the implementation of the Distance Education Modernization Project (DEMP) of the Ministry of Higher Education, which is funded by the Asian Development Bank, several universities have developed DE programmes and DE materials. Both conventional and DE universities are accredited by the Quality Assurance and Accreditation Council (QAAC) of the Ministry of Higher Education. QAAC was established in 2003 to ensure quality, continuous development and efficient performance of Sri Lankan higher education institutions. Working jointly with the Commonwealth of Learning, the ministry produced the Quality Assurance Toolkit for Distance Higher Education Institutions and Programmes (see http://www. col.org/PublicationDocuments/pub_HE_QA_Toolkit_web.pdf) in 2009.

\section{Quality Assurance Systems: Differences and Similarities}

Asia currently has more open and distance teaching universities and more distance learners than any other region in the world (Latchem \& Jung, 2009). The ever-expanding demand and increasing availability, sophistication, and affordability of technology is encouraging governments to urge more institutions to adopt DE, seek new markets, and offer their courses online. However, the biggest challenge facing all of these institutions is how to assure and improve quality, while at the same time widening access, reducing costs, and developing the kinds of mechanisms that will best support such efforts (Jung, 2005). This study revealed that diverse QA systems exist in Asia. Nevertheless, common elements are also clearly noticeable. This section discusses the differences and similarities found in various aspects of the QA systems in the 11 cases studied.

\section{Basic Approaches to QA}

An analysis of the cases shows that Asian countries have adopted three approaches to QA 
in DE.

The first category, as exemplified by Hong Kong, Malaysia, Indonesia, Philippines, Singapore, and Sri Lanka, considers DE as an integral part of higher educational delivery and thus applies the same procedures and criteria to all types of educational provisions. Some show consideration toward the uniqueness of DE during the accreditation or auditing processes.

- Indonesia adjusted its accreditation instrument to accommodate the uniqueness of open and distance higher education programmes (the Accreditation Instrument for Distance Education Study Programmes) in evaluating DE programmes but does not have a separate accreditation process for purely $\mathrm{DE}$ and online programmes.

- The Philippines specifies DE accreditation criteria in the CHED Memorandum Order No. 27 (see http://www.ched.gov.ph/chedwww/index.php/eng/Information/CHEDMemorandum-Orders/2007-CHED-Memorandum-Orders) (Commission on Higher Education, 2005). This stipulated that only graduate-level programs with Level III accreditation could be offered at a distance, with the assumption being that undergraduate students need face-to-face contact with mentors and peers for optimal learning. However, CHED has authorized some institutions, including the University of the Philippines Open University, to offer undergraduate programmes at a distance and officially recognizes them.

- Sri Lanka encourages the use of the Quality Assurance Toolkit for Distance Higher Education Institutions and Programmes (see http://www.col.org/PublicationDocuments/pub_HE_QA_Toolkit_web.pdf) in evaluating and improving QA systems and policies.

- Malaysian Qualifications Agency is currently in the process of developing the Guideline to Good Practices for Open and Distance Learning, which includes 177 benchmarked and enhanced performance indicators (PIs) across nine QA areas. The same nine areas are also used for the programme accreditation and institutional audit of conventional institutions.

- Hong Kong and Singapore use common guidelines and standards for both conventional and DE institutions.

The second category, covering countries such as China, India, and Korea, acknowledges the distinctive features of DE and thus applies different QA procedures and criteria.

- In China, while conventional higher education is evaluated by the General Higher Education Office, DE/e-learning institutions, including OUSC and online colleges, are managed and evaluated by the Distance and Continuing Education Office within the Department of Higher Education of MoE by applying different QA criteria and procedures from those used in conventional institutions. 
- In India, the DEC oversees QA for DE. In 2009, a New Policy on Distance Learning in Higher Education (see http://www.education.nic.in/dl/PolicyDraft-DL.pdf) was introduced, under which all new DE programmes must not only be approved by the DEC but also accredited by the National Board of Accreditation.

- In Korea, KERIS has managed the evaluation of cyber universities using a QA framework that is different from that used for conventional institutions. In the future, however, KCUE and/or other agencies that acquire the government's recognition as an accreditation agency may be put in charge of the quality auditing and accreditation of DE institutions.

The third category, which covers countries like Japan and Mongolia, has yet to determine its position or is in the process of developing QA procedures and criteria considerate of the distinctive features of DE.

\section{Purposes of QA}

Brennan (1999) has suggested seven purposes for QA in higher education: (1) ensuring accountability for public funds, (2) improving the quality of educational provision, (3) stimulating competition within and between institutions, (4) verifying the quality of new institutions, (5) assigning institutional status, (6) underwriting transfer of authority between the state and institutions, and (7) facilitating international comparisons.

In Asian countries, the common rationale behind the adoption of a QA system for DE is to ensure accountability and improve the quality of $\mathrm{DE}$ provision, although several other purposes for QA have also been observed.

To ensure public accountability and assign institutional status, accreditation is often adopted in several cases. Accreditation is the process of external assessment and peer review that determines whether an institution (or programme) qualifies for a certain status or to be recognized or certified as having met certain requirements. The result of accreditation is that an institution or programme either receives or does not receive accreditation. Accreditation for DE institutions or programmes takes place in Hong Kong, India, Indonesia, Japan, Korea, Malaysia, and the Philippines.

Under the aim of improving the quality of DE provision, academic audits are frequently used. Academic audits focus on the processes that an institution has in place to ensure quality. Typically, documents to be submitted include a critical self-analysis report and an external review verifying the self-report via an onsite visit prior to recommendations being made for improvement. A subsequent monitoring process is also put in place. Academic audits ask, "How well are you doing what you say you are doing?" They adopt either performance indicators that are developed and collected at the institutional level or standardized national performance indicators against which institutions are audited. In Asian DE, the regulatory authorities in China, Hong Kong, Japan, Korea, Malaysia, Sri Lanka, and Singapore conduct periodic academic audits. QA also focuses on verifying the quality of new institutions and stimulating competition between DE institutions. This is particularly true 
in China, Korea, and Malaysia, where conventional universities are increasingly providing private DE.

To stimulate competition within and between institutions, performance-based funding has been adopted in a few cases. Performance-based funding ties public funding to the performance of an institution or a programme. In the case of Indonesia, Sri Lanka, and Korea, the outcomes of accreditation or academic audits are directly or indirectly linked to governments' funding decisions.

To provide valuable information that allows the public and policy makers to make decisions and reflect on the customer-oriented focus of DE provision, several countries have made moves to publicly disclose QA information. Performance reporting refers to a QA approach that makes reports on institutional performance available to the public and submits them to government and/or QA authorities. While most Asian countries make the reports public, some countries, such as China, Indonesia, Japan, the Philippines, and Sri Lanka, disclose either the final outcome on the status of accreditation or audits only or limit sharing of the reports to those within institutions and QA authorities.

In the cases of Singapore and Hong Kong, where self-accreditation has been adopted, QA provides the basis for underwriting the transfer of authority between the government and institutions.

\section{Regulatory QA Frameworks}

There exist different types of regulatory frameworks for QA in DE.

- In China and Singapore, the government (MoE) directly regulates QA measures for DE institutions or programmes.

- In Hong Kong, India, Korea, Malaysia, and Sri Lanka, a government QA agency regulates QA in DE.

- Some QA bodies (Korea's KERIS, Indonesia's BAN-PT) are governmental initiatives, and others, as in India, are quasi-governmental structures where the QA agency has a close relationship with the government but is administered by autonomous governing structures. In Indonesia, QA in higher education is enforced both through self-evaluation monitored directly by the Ministry of National Education and accreditation by an independent accreditation agency (BAN-PT).

- In the Philippines, both technical panels organized by a government-operated QA agency and membership-based agencies or professional associations are responsible for QA.

- In Japan's case, three non-governmental membership-based agencies with government recognition regulate QA of higher education institutions.

In Asia, the regulatory approaches covering accreditation and/or academic audits for DE 
institutions/programmes can be either mandatory or voluntary.

- In Hong Kong, Indonesia, India, Mongolia, and the Philippines, accreditation and/or institutional audits are conducted on a voluntary basis, and the outcomes of QA processes are not directly linked to government funding. However, in the case of India and Mongolia, special development funds or government scholarships are given only to accredited institutions.

- In other countries, such as China, Japan, Korea, Malaysia, and Singapore, accreditation and/or periodic audits are mandatory. In China, online institutions that fail to pass their annual academic audit are not allowed to recruit students the following year. In Korea's case, the outcomes of QA activities are directly linked to financial and administrative support from the government. Japan, Malaysia, and Singapore do not link the QA results to governmental funding decisions, but Malaysia links the outcome to a rating system, as well as to levels of institutional autonomy in the case of public universities.

Table 1 outlines these features of the QA regulatory agencies/units in selected Asian countries/territories.

Table 1

Features of QA Regulatory Accreditation Agencies in 11 Asian Countries/Territories

\begin{tabular}{|c|c|c|c|c|c|}
\hline Country & $\begin{array}{l}\text { QA Regulatory } \\
\text { Agency/Unit }\end{array}$ & QA Purposes & $\begin{array}{l}\text { Compulsory } \\
\text { vs. Voluntary }\end{array}$ & $\begin{array}{l}\text { Published QA } \\
\text { Guidelines for } \\
\text { DE }\end{array}$ & Coverage \\
\hline China & $\begin{array}{l}\text { Distance and Con- } \\
\text { tinuing Education } \\
\text { Office of Higher } \\
\text { Education De- } \\
\text { partment of MOE }\end{array}$ & $\begin{array}{l}\text { Institution ac- } \\
\text { creditation and } \\
\text { Academic audit; } \\
\text { Limited perfor- } \\
\text { mance reporting }\end{array}$ & $\begin{array}{l}\text { Compulsory, } \\
\text { every year }\end{array}$ & No & $\begin{array}{l}\text { All OUSC institu- } \\
\text { tions and } 68 \text { on- } \\
\text { line colleges }\end{array}$ \\
\hline $\begin{array}{l}\text { Hong Kong } \\
\text { SAR (China) }\end{array}$ & $\begin{array}{l}\text { Hong Kong } \\
\text { Council for Ac- } \\
\text { creditation of } \\
\text { Academic and Vo- } \\
\text { cational Qualifica- } \\
\text { tions (HKCAAVQ) }\end{array}$ & $\begin{array}{l}\text { Programme ac- } \\
\text { creditation and } \\
\text { Academic audit } \\
\text { (same as institu- } \\
\text { tion review); } \\
\text { Full performance } \\
\text { reporting }\end{array}$ & Voluntary & No & $\begin{array}{l}\text { Both conventional } \\
\text { and DE institu- } \\
\text { tion/ programmes }\end{array}$ \\
\hline
\end{tabular}




\begin{tabular}{|c|c|c|c|c|c|}
\hline India & $\begin{array}{l}\text { Distance Edu- } \\
\text { cation Council } \\
\text { (DEC) }\end{array}$ & $\begin{array}{l}\text { Institution ac- } \\
\text { creditation; Full } \\
\text { performance } \\
\text { reporting }\end{array}$ & Voluntary & $\begin{array}{l}\text { DEC Handbook } \\
\text { on Assessment } \\
\text { and Accredita- } \\
\text { tion of Open \& } \\
\text { Distance Learn- } \\
\text { ing Institutions }\end{array}$ & $\begin{array}{l}\text { DE institutions } \\
\text { only }\end{array}$ \\
\hline Indonesia & $\begin{array}{l}\text { National Accredi- } \\
\text { tation Board of } \\
\text { Higher Education } \\
\text { (BAN-PT) }\end{array}$ & $\begin{array}{l}\text { Programme } \\
\text { accreditation; } \\
\text { Performance- } \\
\text { based funding; } \\
\text { Limited perfor- } \\
\text { mance reporting }\end{array}$ & Voluntary & $\begin{array}{l}\text { Accreditation } \\
\text { Instrument for } \\
\text { Distance Edu- } \\
\text { cation Study } \\
\text { Programmes }\end{array}$ & $\begin{array}{l}\text { Both convention- } \\
\text { al and DE pro- } \\
\text { grammes }\end{array}$ \\
\hline \multirow[t]{3}{*}{ Japan } & $\begin{array}{l}\text { National Institute } \\
\text { of Academic De- } \\
\text { grees and Univer- } \\
\text { sity Evaluation } \\
\text { (NIAD-UE) }\end{array}$ & $\begin{array}{l}\text { Institution accred- } \\
\text { itation; Academic } \\
\text { audit; Limited } \\
\text { performance re- } \\
\text { porting }\end{array}$ & $\begin{array}{l}\text { Compulsory, } \\
\text { every } 7 \text { years }\end{array}$ & No & $\begin{array}{l}\text { Both conventional } \\
\text { and DE institu- } \\
\text { tions }\end{array}$ \\
\hline & $\begin{array}{l}\text { Japanese Univer- } \\
\text { sity Accredita- } \\
\text { tion Association } \\
\text { (JUAA) }\end{array}$ & $\begin{array}{l}\text { Institution accred- } \\
\text { itation; Academic } \\
\text { audit; Limited } \\
\text { performance re- } \\
\text { porting }\end{array}$ & $\begin{array}{l}\text { Compulsory, } \\
\text { every } 7 \text { years }\end{array}$ & No & $\begin{array}{l}\text { Both conventional } \\
\text { and DE institu- } \\
\text { tions }\end{array}$ \\
\hline & $\begin{array}{l}\text { Japanese Institute } \\
\text { for Higher Educa- } \\
\text { tion Evaluation } \\
\text { (JHEE) }\end{array}$ & $\begin{array}{l}\text { Institution accred- } \\
\text { itation; Academic } \\
\text { audit; Limited } \\
\text { performance re- } \\
\text { porting }\end{array}$ & $\begin{array}{l}\text { Compulsory, } \\
\text { every } 7 \text { years }\end{array}$ & No & $\begin{array}{l}\text { Both conventional } \\
\text { and DE institu- } \\
\text { tions }\end{array}$ \\
\hline \multirow[t]{2}{*}{ Korea } & $\begin{array}{l}\text { Korean Council } \\
\text { for University Ed- } \\
\text { ucation (KCUE) }\end{array}$ & $\begin{array}{l}\text { Institution ac- } \\
\text { creditation; } \\
\text { Academic audit; } \\
\text { Performance- } \\
\text { based funding; } \\
\text { Full performance } \\
\text { reporting }\end{array}$ & $\begin{array}{l}\text { Compulsory, } \\
\text { every } 5 \text { years } \\
\text { (Self evalua- } \\
\text { tion: Com- } \\
\text { pulsory, } \\
\text { every } 2 \text { years) }\end{array}$ & No & $\begin{array}{l}\text { Both conventional } \\
\text { 4-year universi- } \\
\text { ties and KNOU }\end{array}$ \\
\hline & $\begin{array}{l}\text { Korea Education } \\
\text { and Research In- } \\
\text { formation Service } \\
\text { (KERIS) }\end{array}$ & $\begin{array}{l}\text { Institution ac- } \\
\text { creditation; } \\
\text { Academic audit; } \\
\text { Performance- } \\
\text { based funding; } \\
\text { Full performance } \\
\text { reporting }\end{array}$ & $\begin{array}{l}\text { Compulsory, } \\
\text { every } 2 \text { years }\end{array}$ & $\begin{array}{l}\text { Cyber Univer- } \\
\text { sity Evaluation } \\
\text { Handbook }\end{array}$ & $\begin{array}{l}18 \text { cyber universi- } \\
\text { ties }\end{array}$ \\
\hline
\end{tabular}




\begin{tabular}{|c|c|c|c|c|c|}
\hline Malaysia & $\begin{array}{l}\text { Malaysian Quali- } \\
\text { fications Agency } \\
\text { (MQA) }\end{array}$ & $\begin{array}{l}\text { Programme } \\
\text { accreditation; } \\
\text { Academic audit; } \\
\text { Full performance } \\
\text { reporting }\end{array}$ & $\begin{array}{l}\text { Compulsory, } \\
\text { every } 5 \text { years }\end{array}$ & $\begin{array}{l}\text { Guideline to } \\
\text { Good } \\
\text { Practices for } \\
\text { Open and Dis- } \\
\text { tance Learning }\end{array}$ & $\begin{array}{l}\text { Both conventional } \\
\text { and DE pro- } \\
\text { grammes }\end{array}$ \\
\hline Mongolia & $\begin{array}{l}\text { Mongolian Na- } \\
\text { tional Council } \\
\text { for Education } \\
\text { Accreditation } \\
\text { (MNCEA) }\end{array}$ & $\begin{array}{l}\text { Institution Ac- } \\
\text { creditation }\end{array}$ & Voluntary & No & $\begin{array}{l}\text { Conventional } \\
\text { institutions only }\end{array}$ \\
\hline \multirow[t]{2}{*}{ Philippines } & $\begin{array}{l}\text { Accrediting Asso- } \\
\text { ciation of Char- } \\
\text { tered Colleges and } \\
\text { Universities of the } \\
\text { Philippines (AAC- } \\
\text { CUP) }\end{array}$ & $\begin{array}{l}\text { Institution/Pro- } \\
\text { gramme accredi- } \\
\text { tation; Limited } \\
\text { performance re- } \\
\text { porting }\end{array}$ & $\begin{array}{l}\text { Voluntary } \\
\text { (3-5 years } \\
\text { depending on } \\
\text { the accredita- } \\
\text { tion status) }\end{array}$ & No & $\begin{array}{l}\text { Public institu- } \\
\text { tions/ pro- } \\
\text { grammes only }\end{array}$ \\
\hline & $\begin{array}{l}\text { Philippines } \\
\text { Accrediting } \\
\text { Association of } \\
\text { Schools, Colleges } \\
\text { and Universities } \\
\text { (PAASCU) }\end{array}$ & $\begin{array}{l}\text { Institution/Pro- } \\
\text { gramme accredi- } \\
\text { tation; Limited } \\
\text { performance re- } \\
\text { porting }\end{array}$ & $\begin{array}{l}\text { Voluntary } \\
\text { (3-5 years } \\
\text { depending on } \\
\text { the accredita- } \\
\text { tion status) }\end{array}$ & $\begin{array}{l}\text { CHED QA Sys- } \\
\text { tem for DE }\end{array}$ & $\begin{array}{l}\text { Both public and } \\
\text { private, conven- } \\
\text { tional and DE } \\
\text { institutions/ } \\
\text { programmes }\end{array}$ \\
\hline Singapore & $\begin{array}{l}\text { MOE’s Quality } \\
\text { Assurance Frame- } \\
\text { work for Universi- } \\
\text { ties (QAFU) }\end{array}$ & $\begin{array}{l}\text { Academic audit; } \\
\text { Full performance } \\
\text { reporting }\end{array}$ & $\begin{array}{l}\text { Compulsory, } \\
\text { every } 4 \text { years }\end{array}$ & No & $\begin{array}{l}\text { Both conven- } \\
\text { tional and DE } \\
\text { institutions/ } \\
\text { programmes }\end{array}$ \\
\hline Sri Lanka & $\begin{array}{l}\text { Quality Assurance } \\
\text { and Accredita- } \\
\text { tion Council of } \\
\text { the UGC/Minis- } \\
\text { try of Education } \\
\text { (QAAC) }\end{array}$ & $\begin{array}{l}\text { Institution/ } \\
\text { Programme } \\
\text { accreditation; } \\
\text { Academic audit; } \\
\text { Performance- } \\
\text { based funding; } \\
\text { Limited perfor- } \\
\text { mance reporting }\end{array}$ & $\begin{array}{l}\text { Compulsory, } \\
\text { every } 5 \text { years }\end{array}$ & $\begin{array}{l}\text { Quality Assur- } \\
\text { ance Toolkit } \\
\text { for Distance } \\
\text { Higher Edu- } \\
\text { cation Insti- } \\
\text { tutions and } \\
\text { Programmes }\end{array}$ & $\begin{array}{l}\text { Both conven- } \\
\text { tional and DE } \\
\text { institutions/ } \\
\text { programmes }\end{array}$ \\
\hline
\end{tabular}

\section{QA Methods and Procedures}

The QA regulatory systems practiced in the 11 Asian countries/territories generally adopt both internal and external reviews and follow four common procedures.

1. Review based on pre-determined QA criteria: A set of QA standards and criteria determined by the government or the QA agency are applied to all institutions or pro- 
grammes. In developing the standards and criteria, nationwide consultations with experts are often sought.

2. Self-assessment (self-study, self-evaluation): The institution (or programme) undergoing the accreditation/academic audit process is required to conduct a self-assessment and report on how it meets the predetermined standards or criteria.

3. External review (peer review): A team of external peers constituted by the QA agency analyzes the submitted documents, including the self-assessment report of the institution/programme, and validates the claims made in the report, generally by visiting the institution.

4. Final decision by the $Q A /$ accreditation agency: Based on the results of the self-assessment and external review, the QA agency makes a final decision.

Some QA agencies (e.g., Japan's NIAD-UE and Mongolia's MNCEA) assist the institutions by providing training on how to prepare a good self-assessment report. Many agencies provide training for external reviewers. In the case of India's DEC, an institution's readiness is assessed before it is put through the formal QA process.

\section{QA Standards and Criteria}

The study revealed that in places where there is a QA system for DE, the QA criteria or guidelines for self-assessment and external review are often specified to cover input, process, and output variables in most if not all of the 12 key areas listed below:

1. Vision, mission, values, and/or goals;

2. Assessment and evaluation;

3. Educational resources;

4. Leadership, governance, and administration;

5. Finance;

6. IT infrastructure;

7. Teaching and learning;

8. Curriculum and course development;

9. Student support;

10. Faculty and staff;

11. Internal QA system; 
12. Research.

Hong Kong, Indonesia, Japan, Malaysia, the Philippines, Singapore, and Sri Lanka apply the same QA criteria for both conventional and distance institutions/programmes. In Mongolia, these QA criteria are applied only to conventional universities. China, India, and Korea have developed specific QA criteria for DE. Table 2 reveals the following:

- Vision, mission, values and/or goals, assessment and evaluation, educational resources, teachingand\& learning, curriculum and course development, and student support are included as QA areas in all 11 cases;

- QA areas like leadership, governance and administration, finance, faculty and staff, and research are included in all cases except in China and the Philippines;

- IT infrastructure is an important QA concern for Hong Kong, India, Indonesia, and Korea, whereas other countries do not assess this area aside from generically under learning support;

- Hong Kong, Indonesia, Japan, the Philippines, and Sri Lanka assess whether or not DE institutions operate an internal QA system, while others do not;

- In the case of Sri Lanka, the Quality Assurance Toolkit for Distance Higher Education Institutions and Programmes lists performance indicators for distance higher education institutions under ten QA criteria, and those of programmes under six criteria that represent the various dimensions of DE practice; these performance indicators are designed to enable institutions to (a) conduct a self-assessment of the performance of their processes in order to make the adjustments and changes necessary for qualitative improvement, and (b) monitor the processes for continuous learning and ongoing improvement. 
Table 2

Key QA Areas for DE in 11 Asian Countries/Territories

\begin{tabular}{|c|c|c|c|c|c|c|c|c|c|c|c|}
\hline \multirow[t]{2}{*}{ QA Areas } & \multicolumn{11}{|c|}{ Countries/Territories } \\
\hline & China & $\begin{array}{l}\text { Hong } \\
\text { Kong } \\
\text { SAR } \\
\text { (China) }\end{array}$ & India & Indonesia & Japan & Korea & Malaysia & Mongolia & Philippines & Singapore & $\begin{array}{l}\text { Sri } \\
\text { Lanka }\end{array}$ \\
\hline $\begin{array}{l}\text { Vision, } \\
\text { Mission, } \\
\text { Values \& } \\
\text { Goals }\end{array}$ & $\checkmark$ & $\checkmark$ & $\checkmark$ & $\checkmark$ & $\checkmark$ & $\checkmark$ & $\checkmark$ & $\checkmark$ & $\checkmark$ & $\checkmark$ & $\checkmark$ \\
\hline $\begin{array}{l}\text { Assessment \& } \\
\text { Evaluation }\end{array}$ & $\checkmark$ & $\checkmark$ & $\checkmark$ & $\checkmark$ & $\checkmark$ & $\checkmark$ & $\checkmark$ & $\checkmark$ & $\checkmark$ & $\checkmark$ & $\checkmark$ \\
\hline $\begin{array}{l}\text { Educational } \\
\text { Resources }\end{array}$ & $\checkmark$ & $\checkmark$ & $\checkmark$ & $\checkmark$ & $\checkmark$ & $\checkmark$ & $\checkmark$ & $\checkmark$ & $\checkmark$ & $\checkmark$ & $\checkmark$ \\
\hline $\begin{array}{l}\text { Leadership, } \\
\text { Governance, } \\
\text { Administration }\end{array}$ & & $\checkmark$ & $\checkmark$ & $\checkmark$ & $\checkmark$ & $\checkmark$ & $\checkmark$ & $\checkmark$ & $\checkmark$ & $\checkmark$ & $\checkmark$ \\
\hline $\begin{array}{l}\text { Financial } \\
\text { Resources }\end{array}$ & & $\checkmark$ & $\checkmark$ & $\checkmark$ & $\checkmark$ & $\checkmark$ & $\checkmark$ & $\checkmark$ & & $\checkmark$ & $\checkmark$ \\
\hline $\begin{array}{l}\text { IT } \\
\text { Infrastructure }\end{array}$ & & $\checkmark$ & $\checkmark$ & $\checkmark$ & & $\checkmark$ & & & & & \\
\hline $\begin{array}{l}\text { Teaching \& } \\
\text { Learning }\end{array}$ & $\checkmark$ & $\checkmark$ & $\checkmark$ & $\checkmark$ & $\checkmark$ & $\checkmark$ & $\checkmark$ & $\checkmark$ & $\checkmark$ & $\checkmark$ & $\checkmark$ \\
\hline $\begin{array}{l}\text { Curriculum } \\
\& \text { Course } \\
\text { Development }\end{array}$ & $\checkmark$ & $\checkmark$ & $\checkmark$ & $\checkmark$ & $\checkmark$ & $\checkmark$ & $\checkmark$ & $\checkmark$ & $\checkmark$ & $\checkmark$ & $\checkmark$ \\
\hline $\begin{array}{l}\text { Student } \\
\text { Support }\end{array}$ & $\checkmark$ & $\checkmark$ & $\checkmark$ & $\checkmark$ & $\checkmark$ & $\checkmark$ & $\checkmark$ & $\checkmark$ & $\checkmark$ & $\checkmark$ & $\checkmark$ \\
\hline Faculty \& Staff & $\checkmark$ & $\checkmark$ & $\checkmark$ & $\checkmark$ & $\checkmark$ & $\checkmark$ & $\checkmark$ & $\checkmark$ & & $\checkmark$ & $\checkmark$ \\
\hline $\begin{array}{l}\text { Internal QA } \\
\text { System }\end{array}$ & & $\checkmark$ & & $\checkmark$ & $\checkmark$ & & & & $\checkmark$ & & $\checkmark$ \\
\hline Research & & $\checkmark$ & $\checkmark$ & $\checkmark$ & $\checkmark$ & $\checkmark$ & $\checkmark$ & $\checkmark$ & & $\checkmark$ & $\checkmark$ \\
\hline
\end{tabular}

\section{International Accreditation}

Several DE institutions in Asia have obtained accreditations from international agencies.

Among the 11 cases in this study, several online education colleges in China and Indonesia's 
UT have obtained ISO 9001. A panel from the International Council for Open and Distance Education (ICDE) has also reviewed UT. The purpose of the ICDE quality review is to boost public confidence in the quality of the standards and services provided to students in DE. The quality review does not involve a review of academic standards of courses or qualifications. It assumes that institutions will be operating within the overall national and/or state legislation as well as within the guidelines that are applicable to them at any given time. Thus, the aims of an ICDE review are to satisfy the public interest in knowing that an institution is (a) providing services to students of an acceptable quality and an appropriate standard in the context of national and regional standards, and (b) exercising its legal powers in a proper manner.

\section{Conclusion}

The level of QA policy integration in an overall national QA in higher education policy framework varies across the 11 cases examined. The experience of these countries/territories that are at different stages of QA system development shows that the QA purpose, policy framework, methods, and instruments are tailored to each country's particular circumstances, as was argued in the ecological model of QA in DE (Jung, 2010) and supported by a survey conducted by the Asia Pacific Quality Network (APQN, 2008). But at the same time, it reveals that there are commonalities that connect the different QA efforts in the cases examined, including the following:

- working toward promoting a culture of quality within QA agencies and DE providers;

- positioning QA in the pursuit of self-improvement and public accountability of DE institutions;

- considering distinctive features of DE in QA frameworks or during evaluation processes;

- linking QA results to direct or indirect funding, levels of autonomy, or other supports;

- adopting both internal and external assessments; and

- making QA results public.

Overall, QA in DE is still at an early stage of development compared with QA in conventional higher education. QA in DE is still a relatively new concept in some countries/territories, and the different QA approaches described above reflect the differences in cultures, expectations, and stages of development. Each of these approaches has its own particular strengths and weaknesses, so it would be invidious to prescribe any single approach. However, in light of these findings, it is suggested that the following principles should underpin national QA policy directions and that without them there will be a considerable waste of resources and human potential in Asian DE. 
- All nations should see QA in DE as an integral part of broader national, regional, and international QA frameworks, as argued by Jung and Latchem (2007), Saito (2009), and Stella and Gnanam (2004). In a cross-border DE context, learners can be distributed anywhere and education can be delivered to them wherever they are. In the nottoo-distant future, learners may take some part of their course from one university, and others from another university, and yet others from a third university within their own nation or beyond. To protect learners from the risks of low-quality programmes and education of limited national and international validity, QA policies in the DE of a nation should be linked to the broader national, regional, and international QA frameworks.

- Concerted efforts are needed from governments, national and regional QA bodies, and institutions regarding cross-border accreditation and QA in Asian DE. Charmonman (2008) observed that while all ASEAN countries are promoting e-learning, there are problems with cross-accreditation that need to be resolved for the sake of educational development and the free flow of skilled manpower. He suggests that all ASEAN governments should either grant recognition to all online degree programmes accredited by another ASEAN government or establish a commission to do this.

- With the convergence of conventional and distance educational methods, there should be no distinctions between QA in DE and conventional higher education or between elearning and face-to-face teaching. However, having said that, specific QA guidelines, criteria, or methods are needed for the various modes of delivery practiced in India, Indonesia, Korea, Malaysia, and Sri Lanka.

- The existence of a national QA framework would enable DE institutions to make QA an integral part of their institutional missions with respect to teaching and research and to promote a culture of quality in their institutions. Koul (2006) suggests the necessity of a "culture of quality" that is shared willingly by all staff members who both draw from and nurture it, links internal and external accountability, builds capacities in QA, and involves open and transparent management and communication. Such a culture entails questioning the status quo, admitting failures or underperformance, acknowledging the changes needed, and implementing these changes. Such behavioral change may well require a considerable paradigm shift in some of Asia's more hierarchical and bureaucratic institutions that currently only pay lip service to the idea of QA, but it is essential if DE is to deliver on its promises and be held in high regard (Latchem \& Jung, 2009).

- Understanding the relative and value-laden nature of QA (Dondi, Moretti, \& Nascimbeni, 2006), Asian governments, DE providers, and assessors should make an effort to understand distance learners' concerns and integrate their views when developing national and institutional QA policies because the success of DE typically relies to a greater extent on learners' motivation and engagement. This learner-centred QA framework has been studied and promoted in several different contexts, such as in Europe (Ehlers, 2004) and Asia (Jung, 2011). 
- As COL (2009) and Shale and Gomes (1998) argue, quality key performance indicators (Q-KPIs) will help DE institutions monitor their performance against institutional objectives and key principles of their plan. DE institutions can use these Q-KPIs in selfassessment for continuous qualitative improvement. In particular, new DE institutions will benefit from using the indicators during formative evaluation and thus to correct and enhance their initial actions.

These policy directions should be further elaborated based on strong research evidence. Future research is needed to investigate culturally considerate QA guidelines and key performance indicators, understand learners' perceptions of DE quality, look into different QA issues in various forms of DE, examine the feasibility of a regional or cross-border QA mechanism for Asian DE, and explore the possibilities of linking with other regions' QA frameworks.

\section{Acknowledgements}

This study was funded by the Openness and Quality in Asian Distance Education project from the International Development Research Centre (IDRC) of Canada. We acknowledge contributions made by Patricia Arinto (University of the Philippines Open University, the Philippines), Aminudin Zuhairi (Universitas Terbuka, Indonesia), Aya Fukuda (International Christian University, Japan), Tsui Kai Cheong (UniSIM, Singapore) and Madhulika Kaushik (formerly of Indira Gandhi National Open University) in supporting the research team to collect and validate the data. 


\section{References}

APQN (2008). Quality assurance arrangements in higher education in the broader AsiaPacific region. Australia: Asia Pacific Quality Network. Retrieved from http:// www.aei.gov.au/AEI/GovernmentActivities/BrisbaneCommunique/Quality_Assurance_pdf.pdf

Brennan, J. (1999). Evaluation of higher education in Europe. In M. Henkel \& B. Little (Eds.), Changing relationships between higher education and the state. London: Jessica Kingsley.

Cashion, J., \& Palmieri, P. (2002). The secret is the teacher: The learners' view of online learning. Leabrook, Australia: National Centre for Vocational Education Research. Retrieved from http://www.ncver.edu.au/research/proj/nroFo3a.pdf

Charmonman, S. (2008, December 11-12). Regional report 2008 on ASEAN universitylevel eLearning. Paper presented at the fifth International Conference on eLearning for Knowledge-Based Society. Bangkok, Thailand. Retrieved from http://www. ijcim.th.org/v16nSP3/o2_fullpaper_Srisakdi_Report.pdf

Commission on Higher Education. (2005). CHED memorandum order No. 27 - Policies and guidelines on distance education. Retrieved from http://202.57.63.198/chedwww/index.php/eng/Information/CHED-Memorandum-Orders/2005-CHEDMemorandum-Orders

COL (2009). Quality assurance toolkit: Distance higher education institutions and programmes. Vancouver: The Commonwealth of Learning. Retrieved from http:// www.col.org/PublicationDocuments/pub_HE_QA_Toolkit_web.pdf

Daniel, J. S. (2003). Mega-universities: Mega-impact on access, cost and quality. Paper presented at the first Summit of Mega-universities. Shanghai, China. Retrieved from http://portal.unesco.org/education/en/ev.php-URL_ID=26277\&URL_ DO=DO_TOPIC\&URL_SECTION=201.html

Dondi, C., Moretti, M., \& Nascimbeni, F. (2006). Quality of e-learning: Negotiating a strategy, implementing a policy. In U.-D. Ehlers \& J. M. Pawlowski (Eds.), Handbook on quality and standardization in e-learning (pp. 31-50). Berlin, Heidelberg, and New York: Springer.

Ehlers, U.-D. (2004). Quality in e-learning from a learner's perspective. European Journal of Open and Distance Learning, I. Retrieved from http://www.eurodl.org/materials/contrib/2004/Online_Master_COPs.html

Hope, A. (1999). Quality assurance. In G. Farrell (Ed.), The development of virtual education: A global perspective (pp. 3-20). Vancouver: The Commonwealth of Learning. 
Jung, I. S. (2005). A review of policy and practice in virtual education: In the context of higher education in S. Korea. Educational Studies, 47, 111-123.

Jung, I. S. (2010). Toward a systemic approach to quality assurance in e-learning: An ecological perspective. Educational Technology International, 11(2), 25-41.

Jung, I. S. (2011). The dimensions of e-learning quality: From the learner's perspective. Educational Technology Research and Development, 59(4), 445-464.

Jung, I. S., \& Latchem, C. (2007). Assuring quality in Asian open and distance learning. Open Learning, 22(3), 235-250.

Koul, B. N. (2006). Epilogue: Towards a culture of quality in open distance learning: Present possibilities. In B. N. Koul \& A. Kanwar (Eds.), Perspectives on distance education: Towards a culture of quality (pp. 177-187). Vancouver: The Commonwealth of Learning.

Latchem, C., \& Jung, I. S. (2009). Distance and blended learning in Asia. New York and London: Routledge.

Perraton, H. (2000). Open and distance learning in the developing world. London: Routledge.

Saito, T. (2009). Quality assurance of distance education/e-learning. Report of Project Group 3: Asia Pacific Quality Network. Retrieved from http://www.apqn.org/files/ virtual_library/project_reports/pg3_project_report_february_2009.pdf

Shale, D., \& Gomes, J. (1998). Performance indicators and university distance education providers. Journal of Distance Education, 13(1), 1-20.

Stella, A., \& Gnanam, A. (2004). Quality assurance in distance education: The challenges to be addressed. Journal of Higher Education, 47(2), 143-160.

\section{Athabasca University $\mathbf{a}$}

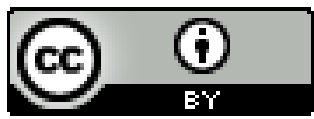

